ne

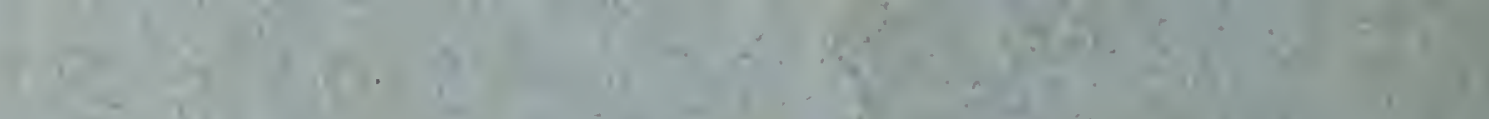

$x^{1}$

1

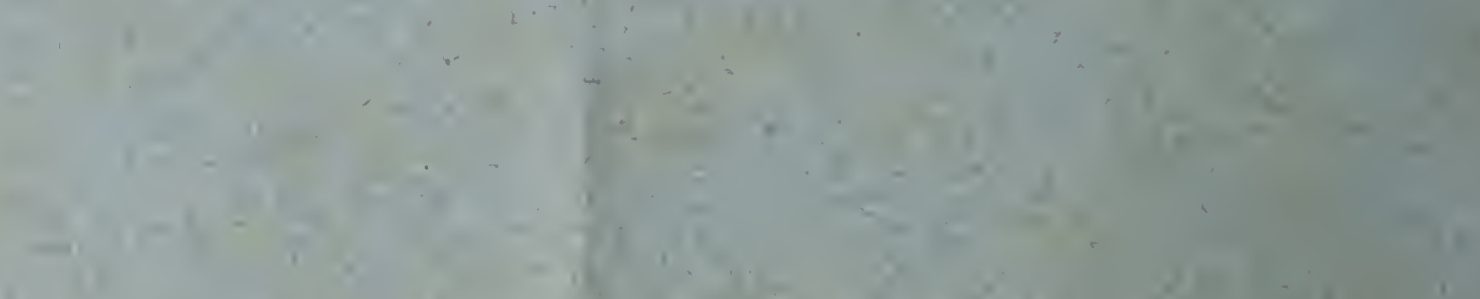

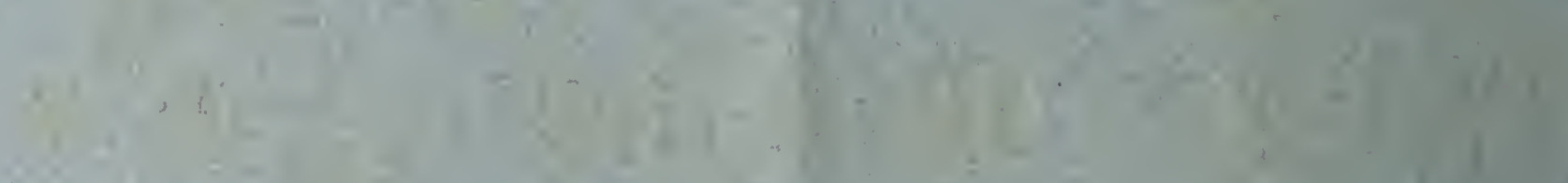

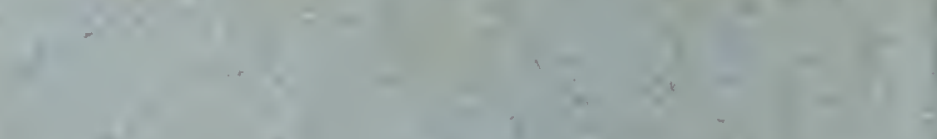

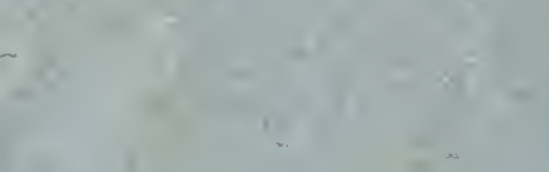

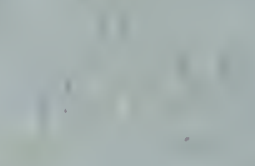

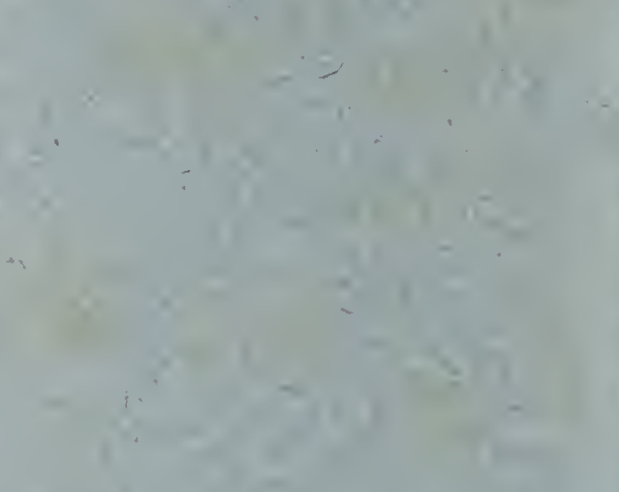

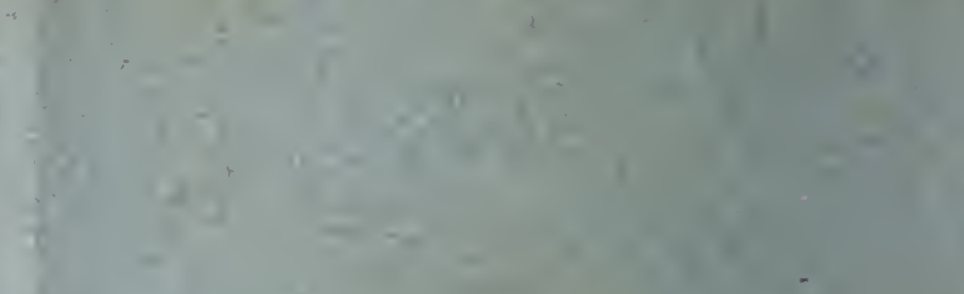

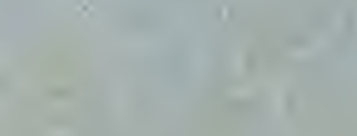

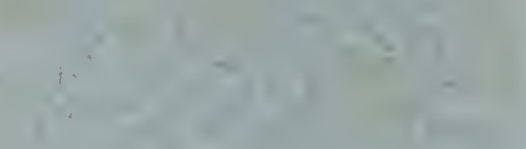

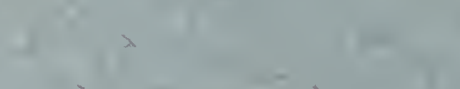

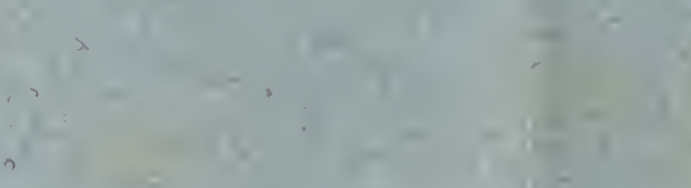

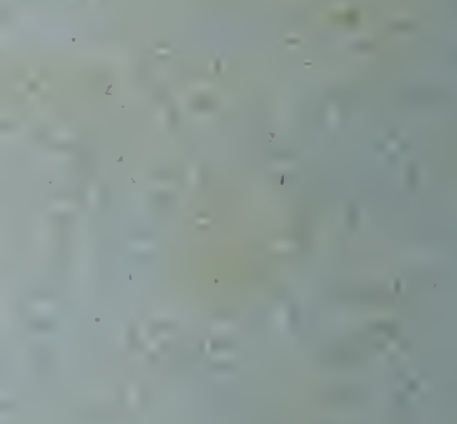

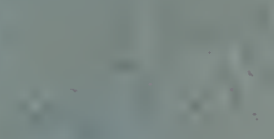

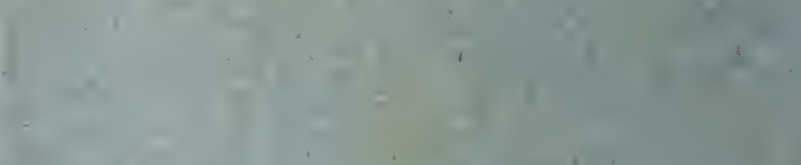
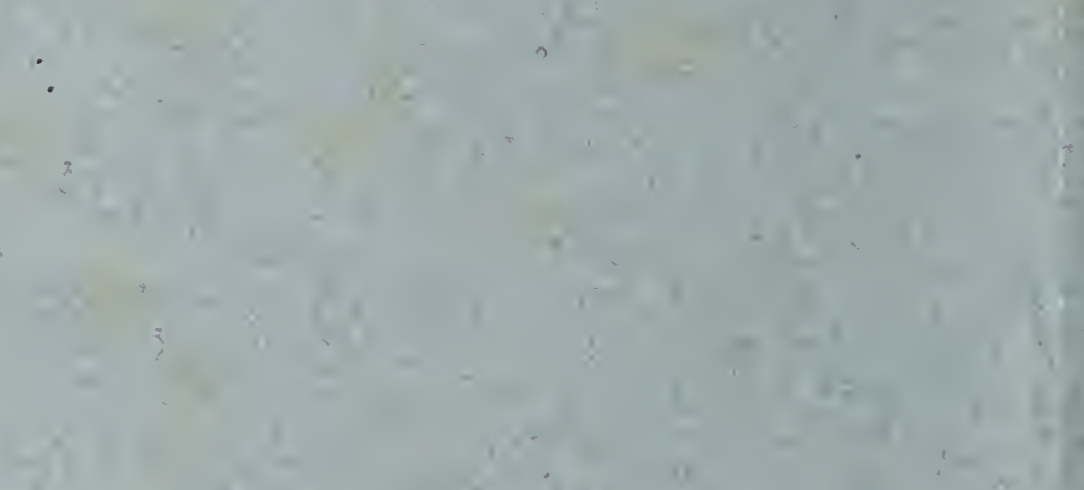

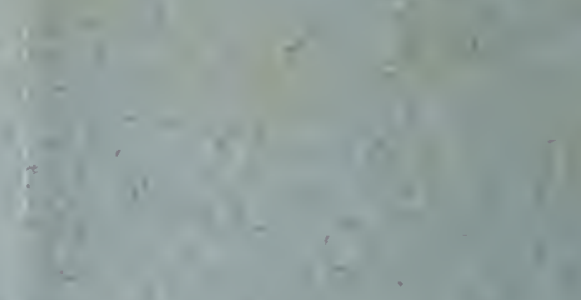

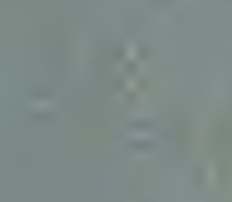

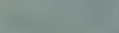

$1=$

$-7$

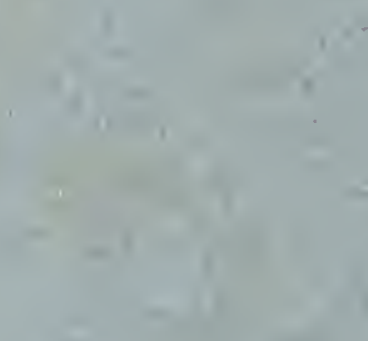

- -1.1

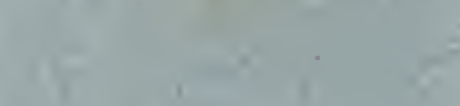

$$
\begin{aligned}
& \text { 2. }
\end{aligned}
$$

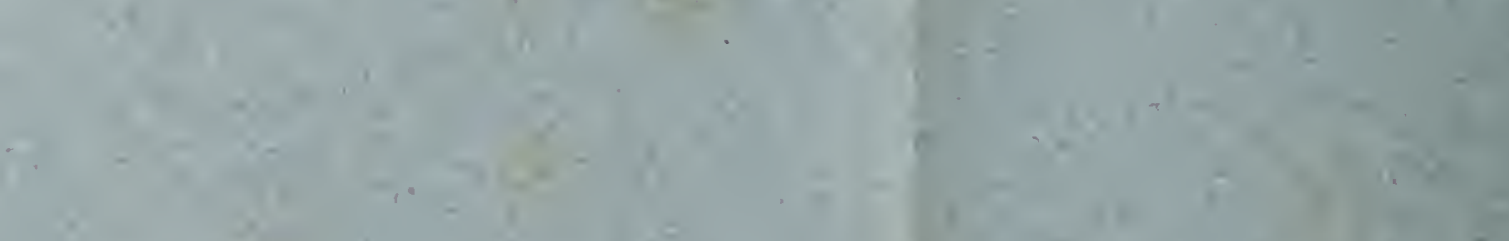

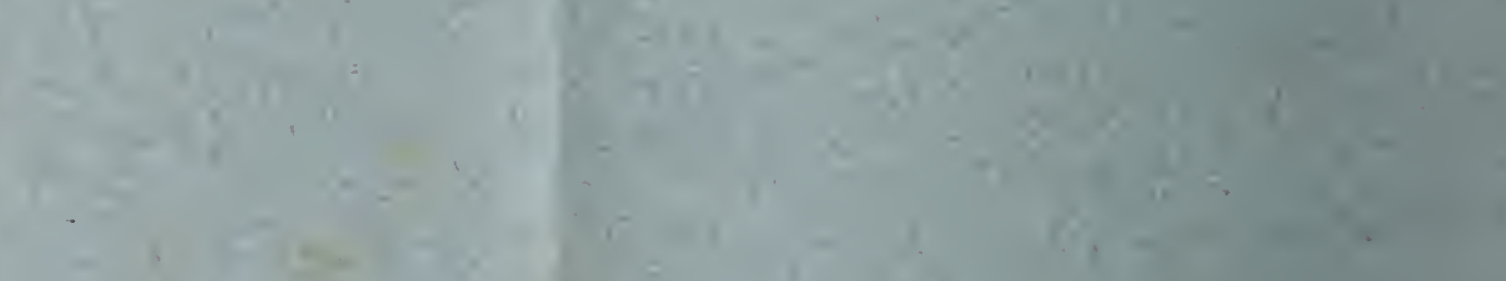

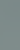




\title{
THE FAUNA OF SCOTLAND,
}

\author{
WITH SPECIAL REFERENCE TO CIMDESDALE AND \\ THE WESTERN DISTRICT.
}

\section{A M M A L I A.}

\section{INTRODUCTION.}

The following Catalogue of Scottish Mammals has been drawn up at the request of the Council of the Natural History Society of Glasgow. In its preparation I have been careful to confine my notes strictly to the department of geographical distribution, and have not entered into any details of description or economy. In the nomenclature I have endeavoured to reconcile the spirit and the letter of the British Association rules, to select the first "clearly defined" name for each species, and at the same time to avoid all unnecessary changes of well-known and generally accepted names.

The numerous scattered memoirs of previous writers liave been collated-notably those of Walker, Low, Fleming, Selby and Jardine, the two Macgillivrays, J. Wilson, Baikie and Heddle, \&c., \&c.-and their observations have been compared with my own field notes and with those of many kind friends and correspondents. Amongst those to whom I am indebted for help are Professors A. Leith Adams, W. Boyd Dawkins, W. H. Flower, and A. Newton, the Rev. G. Gordon, Dr. J. Murie, and Messrs. J. M. Campbell, A. Heneage Cocks, J. G. Gordon, R. Gray, J. E. Harting, J. Kirsop, H. Saunders, and J. R. Tudor. More especially are my thanks due to Professor Turner, of Edinburgh, for many valuable notes on the Seals and Cetaceans, and to Dr. John Alexander Smith, of the same city, for corrections and additions to the account of the extinct forms. Also to Mr. Lumsden, of Arden, who obtained for me lists of the species found in Islay from Mr. M'Kenzie, and of those of Mull from Mr. Cameron; and to Mr. J. A. Harvie-Brown, of Dunipace, who, besides supplying observations from the Outer Hebrides, and rendering much other kind assistance, has procured information as to the Gaelic names from the Rev. Dr. T. M'Lauchlan, of Edinburgh, from $\mathrm{Mr}$. D. Campbell, of Callander, and from other sources. 
The number of well-ascertained recent Scottish Mammals recognized in the following pages is fifty-one, the proportions of the different orders, as compared with the faunas of England and Ireland, being shown in the following Table:-*

\begin{tabular}{|c|c|c|c|c|c|}
\hline DISTRIBUTION OF BRITISH & MAMMAI & LS. & ENGLAND. & SCOTLAND. & IRELAND. \\
\hline I.-ChIRoptera, ... & $\ldots$ & $\ldots$ & 12 & 3 & 7 \\
\hline II.-INSECTIVORA, ... & $\ldots$ & $\ldots$ & 5 & 5 & 2 \\
\hline III.-CARNIVORA, ... & $\ldots$ & $\ldots$ & 13 & 13 & 9 \\
\hline IV.-CE'TACEA, & $\ldots$ & $\ldots$ & 17 & 16 & 11 \\
\hline V.-UNGULATA, & .. & $\ldots$ & 2 & 2 & 1 \\
\hline \multirow[t]{2}{*}{ VI. -GLIRES, } & $\cdots$ & $\cdots$ & 12 & 12 & 7 \\
\hline & & & 61 & 51 & 37 \\
\hline
\end{tabular}

The fifteen English species not hitherto recorded as having occurred north of the Tweed are the following:-

1. Rhinolophus hipposideros.

2. Rh. ferrum-equinum.

3. Vesperugo serotinus.

4. V. noctula.

5. V. leisleri.

6. Vespertilio nattereri.

7. V. bechsteini.

S. V. mystacinus.
9. Synotus barbastellus.

10. Phoca hispida.

11. Balaenoptera laticeps.

12. Grampus griseus.

13. Delphinus delphis.

14. D. albirostris.

15. MIuscardinus avellanarius.

The six Scottish species not yet included in the English fauna are-

1. Trichechus rosmarus.

2. Ziphius cavirostris.

3. Mesoplodon bidens.
4. Delphinapterus leucas.

5. Delphinus acutus.

6. Lepus variabilis.

The four species found in Treland, but not in Scotland, are all Bats, namely-

1. Rhinolophus hipposideros.

2. Vesperugo leisleri.
3. Tespertilio nattereri.

4. V. mystacimus.

* In these Tables I have rejected several speeies of so-called British Bats and Cetaceans as not being well ascertained. Cf. Bell's British Quadrupeds, 2nd ed. (1874). 
Whereas no less than nineteen Mammals ale on the Scottish list, whose presence is not yet əuthenticated in the sister isle:- *
1. Sorex tetragonurus.
2. Crossopus fodiens.
3. T'alpa europaea.
4. Felis catus.
5. Mustela vulyaris.
6. M. putorines.
7. Trichechus rosmaru.
S. Megaptera longimana.
9. Balaenoptera sibbaldi.
10. Hyperoodon laticeps.
11. Ziphius cavirostris.
12. Monodon monoceros.
13. Delphinapterus leucas.
14. Capreolus capraca.
15. Mus minutus.
16. Arvicola agrestis.
17. A. glareolus.
1S. A. amphibins.
19. Lepus europaeus.

From the above Tables it is clear that the principal distinctions between the Mammal-faunas of England and Scotland are to be found in the aerial order of Chiroptera and among the marine Fissipedes and Cetaceans, while that of Ireland differs in the absence of no less than twelve species of land animals. My friend Professor A. Leith Adams has recently shownt that both the recent and the extinct Hibernian Mammals agree with those of Scotland rather than of England, and has given strong reasons for believing that Ireland received this part of its fauna from the south of Scotland, after its separation from Wales and western England. It therefore becomes a point of some interest to compare the fauna of the Scottish Islands with those of the mainland and of Ireland. In such an investigation it is most convenient to restrict our attention to the indigenous terrestrial Mammals, dismissing entirely the Bats, Seals, and Cetaceans, and also the introduced and cosmopolitan Rats and House-Mouse, which may almost be regarded as domestic animals. Taking the Scottish Islands in four principal groups-(I.) the Inner Islands (Skye, Mull, Islay, \&c.); (II.) the Outer Hebrides (the Lews, Harris, the Uists, Benbecula, \&c.); (III.) Orkney; and (IV.) Shetland-we find the distribution of Mammals, as far as I lhave been able to ascertain the facts, to be as shown in the following Table, which represents the known range of twenty-four species of land quadrupeds:-

\footnotetext{
* On the somewhat vexed subject of Irish Mammals 1 have followed the list given by Professor Leith Adams, on the authority of Mr. A. G. More, Proc. R. Dublin Society, 1878, pp. 40, 41, The complete absence from Ireland of some species, as the Common Slirew Weasel, Harrest Mouse, \&c., has becn disputed by some writers.
}

† Proc, R. Irish Academy, 2nd Ser., III., pp. 99-100; Proc. R, Dublin Soc., 1878, p. 42. 
4

\begin{tabular}{|c|c|c|c|c|c|c|}
\hline \multirow{2}{*}{$\begin{array}{l}\text { Distribution of Scottish } \\
\text { ManmaLs. }\end{array}$} & \multicolumn{5}{|c|}{ Scotland. } & \multirow{2}{*}{ 畜 } \\
\hline & 䔍 & 它䓂 & 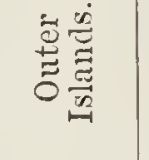 & 它 & 密 & \\
\hline & + & & & & & + \\
\hline \multirow{2}{*}{$\begin{array}{l}\text { 2. Sorex tetragonurus, } \\
\text { 3. S. mimutus, } \quad \ldots\end{array}$} & + & $?$ & & $?$ & & \\
\hline & + & $?$ & + & & & + \\
\hline \multirow{3}{*}{$\begin{array}{l}\text { 4. Crossopus fodiens, } \\
\text { 5. Talpa europaea, } \\
\text { 6. Felis catus. }\end{array}$} & + & + & & + & & \\
\hline & + & & & & & - \\
\hline & + & & & & & \\
\hline 7. Canis vulpes, ... & + & $?$ & & & & + \\
\hline \multirow{2}{*}{$\begin{array}{l}\text { 8. Martes sylvestris, } \\
\text { 9. Mustela vulgaris, }\end{array}$} & + & $?$ & + & & & + \\
\hline & + & & & & & \\
\hline 10. M. erminea, ... & + & + & & & intro. & + \\
\hline 11. Mr. putorius, ... & + & & & & & \\
\hline 12. Meles taxus, $\ldots$ & + & & & & & + \\
\hline 13. Lutra vulgaris, & + & + & + & + & + & + \\
\hline 14. Cervus elaphus, & + & + & + & + & & + \\
\hline \multirow{2}{*}{$\begin{array}{l}\text { 15. Capreolus capraea, } \\
\text { 16. Sciurus vulgaris, }\end{array}$} & + & intro. & & & & \\
\hline & + & & & & & + \\
\hline \multirow{2}{*}{$\begin{array}{l}\text { 17. Mrus sylvaticus, } \\
\text { 18. M. minutus, _.. }\end{array}$} & + & + & $?$ & $?$ & & + \\
\hline & + & & & & & \\
\hline \multirow{2}{*}{$\begin{array}{l}\text { 19. Arvicola agrestris, .. } \\
\text { 20. A. glareolus, ... }\end{array}$} & + & + & + & + & & \\
\hline & + & & & & & \\
\hline \multirow{5}{*}{$\begin{array}{l}\text { 21. A. amplibius,... } \\
\text { 22. Lepus europaeus, } \\
\text { 23. L. variabilis, ... } \\
\text { 24. L. cuniculus, ... }\end{array}$} & + & $?$ & & + & & \\
\hline & + & intro. & intro. & intro. & & \\
\hline & + & intro. & intro. & $\underset{\text { (ext.) }}{+}$ & & + \\
\hline & + & + & + & + & & + \\
\hline & 24 & 7 & 6 & 7 & 1 & 12 \\
\hline
\end{tabular}


The facts indicated by the above Table are, at first sight, somewhat contradictory. As Ireland possesses the greatest number of species in common with the mainland of Scotland, it might well be supposed to have been in connection with it up to a later date than even the Inner Islands. On the other hand we have the presence of other forms, as of the Field Vole in the Hebrides, and of the same species with the Water Shrew and Water Vole in Orkney, which are conspicuous by their absence from the Irish fauna. It appears to me, lowever, that this apparent contradiction may be explained, if we remember the more northern position of the Scottislı Islands and the nature of the country lying between them and the south-western source from which our Mammalian fauna was undoubtedly derived.

A consideration of the relative depths of the channels which respectively divide Ireland and the Islands from the mainland of Scotland would lead us to the conclusion that the severance of the former took place first, and that the Orkneys remained longest uninsulated. An upheaval of about 240-270 feet would bring the latter again into communication with Caithness, while it would require a rise of about 300-320 feet to reunite the Hebrides with Skye, and of from 700 to 900 feet to restore land communication between the various parts of south-western Scotland and northeastern Ireland. Nor does the distribution of Mammal life seem to me to contradict such a hypothesis. The absence from the known fossil fauna of Scotland and Ireland of most of the characteristic postpliocene English animals shows that the northward migration of these forms was slow, gradually advancing as the glacial conditions of the northern parts of our islands decreased in intensity. Thus it is not difficult to suppose that the Hedgehog, Ermine, Badger, Squirrel, and Mountain Hare, may have found their way through southern Scotland into Ireland long before they were able to penetrate into the still sub-arctic regions of the Highlands. Subsequently, when the continued depression of the land had isolated Ireland, and the improvement of the climate had continued, the Shrews and Voles may well have found their way northwards along the comparatively genial coasts, before the larger beasts of prey could find a sufficient stock of game. When they reached Orkney, however, they appear to have found it a veritable Ultima Thule, for the absence from Shetland of any land animal (except the balf-aquatic Otter) seems to indicate that 
those islands were already separated before the arrival of any form of Mammalian life.

Such a hypothesis of the dispersal of English Mammals through Scotland and Ireland appears to me to be the only one which explains the peculiarities of their present distribution, and is likewise in accord with the facts of physical geography. Should it be accepted, the recent and extinct Mammals of Scotland may be arranged in five categories, in the order of the dates of their immigration. This I have attempted to show in the following list, in which the extinct species are marked with an asterisk:-

List of Extinct and Recent Scottish Mammals, arranglid in the PROBABLE ORDER OF 'LIIEIR ARRIVAL FROM THE SOUTHWARD.

I. --Before deposit of boulder-clay :-

*1. Elephas primigenius.

*2. Rangifer tarandus.

II.-Before separation of Ireland:-

3. Erinaceus europaeus.

4. Sorex mimutus.

*5. Conis lupus.

6. C. vulpes.

*(Ursus fossilis. $)^{*}$

7. Martes sylvestris.

S. Mustela erminea.

9. Meles taxus.

10. Lutra vulyaris.

*11. Equus cabullus.

*12. Sus scrofa.

*13. Megaceros giganteus.

14. Cervus elaphus.

15. Scinrus vulgaris.

16. Mus sylvestris.

17. Lepus variabilis.

18. L. curiviculus.

III.-Before separation of Hebrides:-

19. Sorex tetragonurus (?)

*21. Bos longifions.

20. Arvicola agrestis.

IV.-Before separation of the Orkneys:-

22. Crossopus focliens.

24. Arvicola amphibius.

*23. Bos primigenius.

V.--Since separation of Orkneys:-

25. I'alpa curopaea.

26. Felis catus.

*27. Ursus aretos.

28. Mustela vulyaris.

29. $M$. putorius.

*30. Alces machlis.

31. Capreolus capraea.

*32. Castor fiber.

33. Mus mimutus.

34. Arvicola glareolus.

35. Lepus europaeus.

I now proceed to the consideration of the details of the distribution of the species, taking first the recent, and second the fossil and extinct forms.

LONDON, 1850.

* Renains of the Cave Bear have not yet been found in Seotland, but its former existence is rendered probable by their presence in Irish denosits.-Cf. A. Leith Adams, loc. cit. 


\section{RECENT SPECIES.}

\section{ORDER 1. : CHIROPTERA. \\ Family: VESPERTILFONIDAE. \\ 1. Plecotus auritus (Linnaeres).}

Long-eared Bat.

Not uncommon in the southern and central counties, but rarer in the north. It occurs in Arran, Islay, Mull, and probably in the other Inner Hebrides, but has not been recorded from the Outer Islands, nor from Orkney or Shetland.

[Rhinolophus inpposideros (Bechstein). -The Lesser Horseshoe Bat is stated by Dr. A. R. Young to have occurred, along with the last species, at Crookston Castle, Renfrewshire (New Stat. Acc. Renfi., p. 162). All inquiries as to the fate of the specimen have been in vain, and I greatly suspect a mistake in identification.]

\section{Vesperugo pipistrellus (Schreber).}

Common Bat.

Scot., Bak, Bakie, Backie-kird (S'wed., Natt-baka, a bat; Old Norse, blaka, to flap); Gael., Ialtag, Dialtag.

Much the commonest species of Bat in Scotland, extending quite to the north of the mainland, but rare in some localities, as in the west of Sutherlandshire, where I have only once seen a specimen. It is common in Arran, Islay, and Mull, but appears to be scarce in the Outer Islands. The late Capt. M'Donald, of Rodil, told Mr. Harvie-Brown that he had only once seen a Bat in Harris, and Baikie and Heddle mention a few instances of their occurrence in Orkney (Hist. Nat. Orc., p. 14).

[Vesperugo noctula (Schreber).-Fleming identified the Vespertilio auriculatus of Walker's "Fauna Scotica" (Essays Nat. Hist., p. 472) with this species (Brit. An., p. 6), but the description agrees much better with $V$. darebentoni. The Great Bat is also stated by the late Sir William Jardine to have been seen near the River Annan, in Dumfriesshire (New Stat. Acc. Dumfr., p. 175), but its occurrence in Scotland has not been confirmed. The most northern English locality which has been recorded is Northallerton, in Yorkshire (Bell's Brit. Quad., 2nd ed., p. 23).] 
[Atalapha cinerea (Becuvois). Under the name of Vespertilio pruinosus, Say, the late $\mathrm{Mr}$. Wolley recorded the capture of a specimen of this American species in South Ronaldsha, Orkney, in 1847 (Zoologist, 1849, p. 2343; op. cit., 1850, pp. 2695, 2813). As he himself suggested, there can be little doubt that it was accidentally brought over in a ship. As far as I am aware this is the only known instance of an exclusively American bat having been taken in Europe.]

\section{Vespertilio Daubentoni, Leisler.}

Daubenton's Bat.

Appear's to be pretty widely distributed on the. mainland, but to be local. It was first correctly identified as a Scottish species by William Macgillivray, who took it in Aberdeen Cathedral, in 1840 (Edin. N. Phil. Joumn., xxxi., p. 205), and Jolnn Macgillivray captured eighty individuals in two clusters in the same building (Ann. and Mag. Nat. Hist., viI., p. 230). Fleming had already recorded its occurrence in Fifeshire under the name of $V$. emarginatus (Brit. An., p. 6); Macgilliviay found it in Dumfriesshire (Nat. Libr., xxiı., p. 95); Mr. R. Gray tells me he has met with it in Kirkcudbright; a specimen captured in Glasgow Green, is preserved in the University Museum (Alston, P. N. H. S. Glasg., I., p. 203); and another, caught in the West-end Park, has been lately submitted to me by Mr. J. M. Campbell. As above remarked, this probably may be the $V$. auriculatus of Walker, but his description is quite insufficient for certain identification, otherwise his name would take priority of Leisler's.

\section{ORDER II.: INSECTIVORA. \\ Family: ERINACEIDAE.}

4. Erinaceus europaeus, Linnclers.

Hedgehog.

Scot., Hurchin, Hyrchoune (Barbour). (From Old French, Eriçon, a hedgehog, or fiom Low Germ., hurken, to crouch or curl ?)

Gael., Crainaig.

Very common in the Lowlands, and rapidly spreading to the northward, but has not yet been met with in Sutherlandshire. 
The Rev. G. Gordon informs me that it is increasing in numbers in Morayshire, where it was formerly rare. Mr. Colquhoun says that it is common in Bute (Sporting Days, p. 101), but it is unknown in Arran, Mull, Islay, the Hebrides, Orkney and Shetland. The history of the increase of range of this and the next species in Scotland would well repay careful investigation.

\section{Family: TALPIDAE.}

\section{Talpa europaea, Linnaens.}

Mole.

Scot., Moudie, Moudiewart (Old English, Mouldwarp, a mole; Angl. Sax., molde, soil, weorpan, to throw); Earth-hound (Aberdeen).

Gael., Famh, Uir-reathaldh, Uireabh (lit., earth-plougher).

Like the last species, the Mole has greatly extended its range of late years, and is now well known throughout the mainland to Sutherlandshire and Caithness. Thirty-six years ago it was recorded as spreading rapidly in west Argyllshire (New Stat. Acc. Argyl., pp. 380, 439). In Mull it is said to have been accidentally intrcduced in a boat-load of earth from Morven early in the last century, but it appears to be unknown in the rest of the Scottish Islands.

\section{Family: SORICIDAE.}

\section{Sorex tetragonurus, Ierman.}

Common Shrew.

Scot., Shrew-mouse; Orc., Sheer-mouse.

Gael., Daltag, Daltag-fheior (from Gael., dall, blind, and fheoir, grass).

Common in all the mainland counties, as it is said to be in Arran, Islay, and Mull; "not very numerous" in Orkney (Hist. Nat. Orc., p. 14), but some doubt remains as to whether it is not the next species that is found there. According to W. Macgillivray, the Common Shrew is found in the Outer Hebrides on sandy pastures, where it is termed Luch-fheior (Edinb. Journ. Nat. and Geogr. Sc., II., p. 162), a name properly belonging to the Field Vole (infra, p. 28); but, as will be seen directly, the Hebridean Shrew is Sorex minutus. 


\section{Sortix minutus, Linnaers.}

Lesser Shrew.

Has been generally confounded with the last species, and appears to be generally less numerous. J. Macgilliviay, who first recorded it as a Scottish animal under Jenyns' name of S. rusticus, considered it to be as abundant as the Common Shrew near Aberdeen (Ann. and Mag. Nat. Hist., viıi., p. 23), and the Rev. G. Gordon tells me that specimens which he sent to Mr. Jenyns from Morayshire were identified by that gentleman with the same species. In the south-west it is not rare in the Upper Ward of Lanarkshire (Alston, Faunce W. Scotl., p. v.). Mr. Harvie-Brown has recently sent me an example of the Shrew of the Outer Hebrides, caught by him this summer in South Uist, and I was much interested in finding that it belonged to this species, the only one yet positively known to occur in Ireland.

\section{S. Crossopus fodiens (Pcullas).}

Water Shrew.

Gael., Famh-uisge (lit., water-mole).

Both the white-throated form and the dark rave, formerly separated as $C$. remifer (Geoffroy), are widely but locally distributed throughout the mainland, and intermediate varieties constantly occur. The species was first added to the Scottish fauna by the late Dr. Scoular, who took specimens near Glasgow (Mag. Nat. Hist., VI., p. 512), and it has since been found as far north as Sutherlandshire, where it is not uncommon. Baikie and Heddle state that one was killed in Waas, Orkney (Hist. Nat. Orc., p. 14), and it is not rare in Arran, but I have been unable to ascertain its existence in any of the other Islands.

\section{ORDER III.: CAR N V ORA. Family: HELIDAE.}

\section{Felis catus, Limnaers.}

Wild Cat.

Gael., Cat-fhiadhaich (lit., wild cat), Braiene.

Once generally distributed over the mainland, the Wild Cat has been totally extirpated in the Lowlands and in many parts of the Highlands. It is still to be found, however, in the wilder districts of most of the northern counties, especially in the deer-forests, 
where it is left comparatively undisturbed. Till of late years its southern outpost was the mountainous country around Loch Lomond, whence there are specimens in the Glasgow University Museum; but it is now extinct in that neighbourhood (Lumsden, P. N. H. S. Glasgow, III., p. 189), and I believe that none now exist south of the northern districts of Argyll and Perthshire. There appears to be no evidence that the Wild Cat was ever found in any of the Islands, Pennant's statement that it was a native of Arran being probably erroneous.

\section{Family: CANIDAE.}

\section{Canis vulpes, Limnaers.}

Fox.

Scot., Tod (Old Islandic, toc, a fox).

Gael., Sionnach, Balgair, Madadh-ruadh (lit., red hound).

Universally distributed on the mainland, both in the Lowlands and Highlands, but absent from the Islands, except Skye (Duns). In Mull there is a tradition that Foxes were formerly found, but were exterminated about the middle of the last century.

\section{Family: MUS'TELIDAE.}

\section{Martes syluestris, Nilsson.}

Yellow-breasted Marten.

Scot., Mertrick (Ang. Sax., mearth, a marten).

Gicel., Taghan (fiom Gael., taghanach, surly, sulky?).

Like the Wild Cat, the Marten has been exterminated in most parts of the Lowlands, but a few still linger in some parts of the south-west. Macgilliviay mentions a Lanarkshire specimen ( Nat. Libr., xxı., p. 168), and one was killed in Ayrshire, near Maybole, in 1876 (Alston, Fcunce W. Scotl., 1) vi.). In the Highlands also it is much reduced in number's, and in many places is already quite extinct, but still finds a refuge in the wilds of most of the counties north of Perth and Argyll, especially in the deer-forests. It does not appear to be a native of any of the Inmer Islands, but, curiously enough, is well known in the Outer Hebrides, where it was noted as far back as 1715 by Martin (West. Isles, 1. 36). When Macgillivray wrote (1838) it was "abundant" in Harris, but Mr. Harvie-Brown informs me that it is now almost exterminated there. 
[Martes Foina (Limnaeus). - The White-breasted Marten has been constantly included in lists of Scottish Mammals, but there appears to be no evidence of its ever having been found in any part of Britain. The older writers trusted entirely to coloration, and consequently confused any pale-breasted specimens with the common continental species. The two forms may be readily distinguished, however, by the colour of the under-fur, and by several cranial and dental characters, of which the most striking are these :In $M$. foina the under-fur is greyish-white, and the last upper molar is notched externally, whereas in $M$. sylvatica the under-fur is reddish-grey, and the last upper molar is simply rounded externally ( $f f$. Alston, P. Z. S., 1879, pp. 468-474; Zoologist, 1879, pp. 441-448).]

\section{Musiela vulgaris, Erreleben.}

Common Weasel.

Scot., Whitrit, Quhittrit (from Scot., quhid, to move swiftly?) Common to the next species.

Gael., Neas, Nios (from Gael., nimh, poison?) Common to the next species.

Found throughout the mainland, although hardly so common in most places as the next species. It is not a native, however, of any of the islands, except Bute, where Mr. Colquhoun says it is rare (Sport. Days, p. 100). As will be seen presently, the statements of Low and of Baikie and Heddle, as to the Common Weasel having been introduced into Shetland, are erroneous.

\section{Mustela erminea, Linnaers.}

Stoat or Ermine.

Scot. and Gael. (See last species.)

Generally a more plentiful species than the last in Scotland, and found in most of the Inner Islands, being extremely common in Skye, Mull, Bute, and Islay, but it is not found in Arran, the Outer Hebrides or Orkney. From information supplied to me by Mr. J. R. Tudor and Mr. Howard Saunder's, it appears that the "Weasels" of the Mainland of Shetland are really Stoats. According to Low (Funn. Orc., p. 29) they were introduced through malice, and the assertion of Baikie and Heddle (Hist. Nat. Orc., p. 11), that they became extinct, is incorrect-they are still over-abundant. 
Polecat.

\section{Mustela putorius, Linnaers.}

Scot., Foumart (also Old and local English).

Gael., Fochlan (from Gael., fochal, dirt?).

Now rare or extinct in many of the southern counties, and locally rather than generally distributed in the Highlands. It is not found in any of the Islands.

\section{Meles taxus (Schreber).}

Badger.

Scot., Brock (from the Gaelic? or from Scot, broakit; Danish, broged, spotted, striped. Also Old and local English ?)

Gael., Brochd (from Gael., broc, mottled grey?).

The Badger, now, like the Polecat, a very scarce animal in the south, has been recorded of late years from Lanarkshire (Alston, Faunc W. Scotl., p. vi.) and Kirkcudbright (R. Service, Zoologist, 1878, p. 427), and Mr. Harvie-Brown informs me that it appears not to be very rare near Yetholm. It is still far from uncommon in suitable localities in the Highlands, but is unknown in the Islands.

\section{Lutra vulgaris, 'Erxleben.}

Otter.

Shetl., 'Tyke.

Gael., Dobhran, Dorchie (from dobhar, water?); Beast-dhu, Madadh-donn (lit., brown hound); Balgar in the Hebrides (which is properly the fox).

Although reduced in numbers by persecution, the Otter is universally distributed along river-courses and around lakes, and on the northern and western shores it is found wherever a rocky coast provides it with a suitable dwelling-place. It is also a native of all the principal Scottish Islands.

\section{Family: PHOCIDAE.}

\section{Phoca vitulina, Limnaens.}

Comimon Seal.

Scot., Selch, Selcht, Selchie (Old German, Selach).

Gael.; Ron.

Found round the coasts in all localities where it is comparatively free from intrusion, especially on the north and west shores, and among the Islands. 
[Pнioca mispida, Schreber.-The Ringed or Marbled Seal may perhaps be the "Bodach" (lit., old, man) of the Hebrideans, a small and rare species reported by M'Neil of Colonsay to the late Mr. J. Wilson (May. Zool. and Bot., I., p. 541-544). No recent Scottish specimens lave, however, been yet recorded, although fossil remains in brick-clays of various localities have been identified by Prof. Turner (P.R.S. Edin., 1869-70, pp. 105-114, and Jour. Anat. and Phys., IV., pp. 260-270). One specimen has been taken on the coast of Norfolk (Bell's Br. Qued., 2nd ed., p. 249), and the supposed existence of the species in the Hebricles is worthy of further investigation.]

\section{Phoca grofniandica, Fabricins.}

Greenland or Harp Seal.

There can be little doubt that this large Seal occasionally visits the coasts of Scotland, although the existing records are far from satisfactory. Macgillivray doubtfully referred a young Seal taken in the Firth of Forth to the present species, and mentions a second specimen in the University Museum of Edinburgh (Nai. Libr., xxir., p. 210), but Prof. Turner informs me that the latter cannot now be identified. The late Mr. H. D. Graham believed that he saw three examples in Jura, and thought that the species was confused by the islanders with the Gray Seal under the name of "Tapvaist" (P.N.H.S. Glasg., I., pp. 53-54); and Mr. HarvieBrown saw what he fully believes to lave been four examples of Phoca groentandica in the Sound of Harris in 1870. The late Dr. Saxby says that the Greenland Seal is not very rare in Shetland during bad weather (Zoologist, 1864,p. 9090); but the only thoroughly well-authenticated British-killed specimen yet recorded is one in the Kendal Museum, which was taken on the coast of Lancashire in 1868, and identified by Mr. Thos. Gough and Prof. Turner (Jour. Anct. and Phys., Ix., pp. 163-165).

Hooded Seal.

\section{Cystophora cristata (Erxleben).}

A rare straggler. Baikie and Heddle state that specimens are "said to have been killed at Rousay and at Papa Westra," and give the Orcadian name of "Bladder-nosed Seal," by which the species is well known to the northern whalers (Hist. Nat. Orc., pp. 13, 98), and Mr. Howard Saunders was this year assured that the 
"Bladder-nose" is well known as a visitor to the Vae Skerries, Shetland. A young example was killed near St. Andrews on the 22nd July, 1872, as recorded by Mr. R. Walker (Scot. Nat., II., p. 1), and two others have been obtained on the English coasts. As far back as 1577 mention is made in Hollinshed's "Cronicle" of "sundry fishes of monstrous shape, with cowls over their heads like unto Monks and in the rest resembling the body of Man," whose appearance in the Firth of Forth was followed by pestilence and murrain. These may not improbably have been Hooded Seals.

Gray Seal.

\section{Halichoerus gryphus (Fabricins).}

Orc., Haaf-ish.

Gael., Tapvaist (in the Hebrides).

Very abundant on the rocky shores of the Outer Hebrides, where the great breeding-place at Haskeir, off North Uist, has often been described, and among the Orkney and Shetland Islands. Comparatively rare on the coasts of the mainland, especially on the east; but Prof. Turner has recorded it from near Montrose and St. Andrews, and believes it to be more common than is usually supposed on the east coast, where the Tay fishermen call it the "Black Seal" (Jour. Anat. and Phys., IV., p1. 270-271). The Gray Seal was formerly confused with the Arctic Phoca barbata, but there is no good evidence that the latter has ever visited the British coasts (cf. Bell's Br. Quad., 2nd ed., pp. 238, 263).

\section{Family: TRICHECHIDAE.}

\section{Trichechus rosararus, Linnaeus.}

Walrus.

Now a very rare straggler, though it was probably a more frequent visitor to our coasts in old times. Sir R. Sibbald mentions it on the authority of Boethius, and its remains have been found in peat-bogs in England. One was killed at Caolas Stocnis, on the east coast of Harris, in December, 1817, and was examined by Macgillivray (Nat. Libr., xxII., p. 223). A second, shot in June, 1825, on Edday, Orkney, was recorded by Mr. R. Scarth (Edin. Phil. Mag., xin., p. 383), and its head is preserved in the University Museum at Edinburgh. A third is reported by Baikie and Heddle to have been seen in Hoy Sound in 1827 (Hist. Nat. Orc., p. 14), and a fourth was killed in April, 1841, on the East Heiskar, near 
Harris, as recorded by Dr. R. Brown (Ann. and Mag. Nat. Hist, 4th Ser., vII., p. 65), who has been further informed of two being seen about Orkney and Shetland in 1857 (P. Z. S., 1868, p. 433).

\section{ORDER IV.: CETACEA. \\ [Family: BALAENIDAE.]}

[Balaena mysticetus, Limaeus.-The Greenland Right-Whale has generally been included in Scottish lists, but the Right-Whale which certainly visited the British seas in old times was probably the more southern species, B. biscayensis, Eschricht, which appears to be now almost extinct on the European side of the Atlantic. There is, however, no authentic evidence of the occurrence of any Right-Whale on our coasts in modern times, most of the records being referable to one or other of the Rorquals (cf. Bell's Br. Quad., 2nd ed., pp. 381-391).]

\section{Family: BALAENOPTERIDAE.}

\section{Megaptera longinana (Rudolphii).}

Hump-backed Whale.

Only one authenticated specimen of this large Cetacean has been captured in the Scottish seas, an adult measuring in length 48 feet, which was towed into Wick Bay in March, 1871; its pectoral limbs each measured 14 feet. A description of this specimen was published by Mr. W. Reid, in "Land and Water" (1st April, 1871); the skeleton was not preserved, but Prof. Turner obtained some of the baleen for the Anatomical Museum of the University of Edinburgh. The species has also occurred at least twice on the English coasts (cf. Bell's Brit. Quad., 2nd ed., p. 394).

\section{Balaenoptera musculus (Linncleus).}

Common Rorqual, or Razor-back.

Orc., Finner. (Common to next two species.)

Appears not to be uncommon off the Orkney and Shetland Isles; three, taken there in 1856, were described by Dr. Duguid (P.Z. S., 1856, p. 187), and distinguished as a new species, Physalus duguidii, by Gray (Cat. Seals and Whales, p. 15s; cf. Bell's Br. Quad., 2nd ed., p. 399). A number of other large Rorquals have been recorded as occurring on the shores of the mainland and in the 
Hebrides. Thus Prof. Turner tells me that one was stranded in 1848 near Kingask, Fife, and another was brought into Stomoway in 1871, specimens of the baleen of both of which animals are in his possession. Again, one was stranded at Wick in 1869, and another towed into Peterhead in 1871, portions of the skeletons of both of which are in the Museum of the University of Aberdeen, and have been described by Dr. Struther's (Jour. Anat. and Phys., vi., pp. 107, 125). But in most cases the descriptions liave not been sufficiently exact to enable zoologists to determine whether they belonged to this or the next species. In future it is to be hoped that the number of the ribs and vertebrae of such visitors will be noted, and specimens of their baleen (or whale-bone) retained, even when it is not practicable to preserve the whole skull.

\section{Balaenoptera sibbaldi (Gray).}

Sibbald's Rorqual.

Orc. (See last species.)

This very large Rorqual has repeatedly occurred on the eastern coasts of Scotland. The specimen stranded near Abercorn in 1692, and described by Sir Robert Sibbald, was probably of this species. One about $80 \mathrm{ft}$. long was found dead in October 1831 near Nortl Berwick, and its skeleton, prepared by Dr. Robert Knox and $\mathrm{Mr}$. Frederick Knox, is now in the Museum of Scienceand Art, Edinburgh. In November 1869 a gravid female of $78 \mathrm{ft}$. in length was stranded in the Firtl of Forth, near Longniddry, and was carefully described in the Transactions of the Royal Society of Edinburgh (xxvi., pp. 197-251, pls. v.-viii.), by Prof. Turner, who also states that one about $90 \mathrm{ft}$. long came ashore witlı its sucker at Hamna Voe, Shetland, in October of the same year. The Longniddry skeleton is now in the Anatomical Museum of the University of Edimburgh. Prof. Turner has also obtained the skeleton of a specimen stranded at Wick in 1871, and the ear-bones and nasals of one stranded at Aberdour, Fife, in 1858.

\section{Balaenoptera rostrata (Fabricius).}

Lesser Rorqual.

This comparatively small species is a not unfrequent visitor to the northern and eastern coasts, more rarely to the western. One was taken near Largo in 1832; and in the Anatomical Museum of the University of Edinburgh is preserved the skeleton of a young 
one captured near Queensferry in February 1834, and prepared by Dr. Robert Knox. Prof. Turner tells me that in the same Museum is the skull and baleen of a specimen stranded at Burntisland in 1870, the skull and baleen of one taken at Dunbar in 1871, and some baleen-plates of one caught in the herring nets off Anstruther in 1872. Another specimen was caught in the Firth of Forth in 1858. The Lesser Rorqual has also been recorded from Shetland, and the skull of one which was cast ashore on Islay in 1866 is now in the Museum of the University of Cambridge. In the Museum of Anderson's College, Glasgow, there is a sub-fossil skull of a small Whale, which was found in lrick-clay near Stirling, which is probably referable to this species.

[Balaenoptera laticeps (Gray).-Rudolphi's Rorqual has been supposed to visit our shores, the Islay Rorqual mentioned above having been referred to this rare species by MM. Gervais and Van Beneden (Ostèogr. des Cétacés, I., p. 200). Mr. J. W. Clark, however, informs me that a more careful examination of the skull at Cambridge shows that it belonged to the last species.]

\section{FAMily: PHYSETERIDAE.}

\section{Physeter macrocephalus, Linnaeus.}

Sperm-Whale, or Cachalot.

Stray individuals, usually old bulls, occasionally wander from the semi-tropical seas, and Prof. Turner has collected evidence of at least eight authentic occurrences on the coasts of Scotland. A tooth was found by $\mathrm{Mr}$. G. Petrie in a structure at Hoxay, Orkney, which probably dates from the 9th or 10th century (T'urner, P. R. S. Edin., 1871-2, p. 638). A male, 52 feet long, came ashore at Limekilns, on the Forth, in February 1689, as recorded by Sir Robert Sibbald, in his "Phaliinologia Nova," and another, about the same size, at Cramond in 1701 (Turner, op. cit., 1870-1, p. 367). One of 57 feet in length was taken at Monifieth in February 1703 (op. cit., p. 368), and one of 63 feet on the west const of Ross-shire in 1756 (Hamilton, Nat. Libr., xvi., p. 179). A second example ran ashore at Cramond in December 1769. It was also a male, measuring 54 feet, and was described by Robertson in the Philosophical Transactions of 1770. Low mentions two taken in Hoy Sound about 1800, and says that the species "is often drove ashore about the Orkneys" (Foun.Orc., p. 161). One, said to have been about 60 feet long, was 
killed near Oban, in May 1829 (L'umer, P. R. S. Edin., 1870-1, p. 365), and a large male was washed ashore near Thurso in July 1863. The skeleton of the latter is now in the British Museum, and is described in Prof. Flower's admirable monograph (Tr. $Z$. S., VI., pp. 309-372). Lastly a male, said to be nearly 60 feet long, was stranded in Loch Scavaig in Skye, in July 1871 (Turner, P. R. S. Edin., 1871-2, p. 632). Several others have occurred from time to time on the English coasts.

\section{Hyperoodon rostratus (Chemnitz).}

Common Beaked-Whale.

A much more frequent visitor to our shores than any of the preceding species, specimens being killed almost every autumn on some parts of the coast. Fishermen usually confound it with the other smaller Whales under the names of "Bottle-nose," "Grampus," and "Muc-mhara." Two crania of this Whale are in the Anatomical Museum of the University of Edinburgh, one from a specimen caught at Queensferry and the other from one killed in Hamna Voe, Shetland.

\section{Hyperoodon latifrons, Gray.}

Broad-fronted Beaked-Whale.

This Whale has only been distinguished from the last by its skull, its exterual characters remaining still undescribed. The skull on which Gray founded the species was sent from Orkney, and passed through Warwick's collection to the British Museum (Zool. "Erebus" and "Terror," I., p. 27). A female, 28 feet in length, was taken in the Firth of Forth in October 1839, and its skeleton is preserved in the Edinburgh Museum of Science and Art (Gray, Cat. Seals and Whales, p. 339). As far as is at present known, the Broad-fronted Beaked-Whale would appear to be everywhere a rare animal.

\section{Ziphitus cavirostris, Cuvier.}

Cuvier's Whale.

The only recorded British specimen of this little known Cetacean was taken off Hamna Voe, Mainland of Shetland, in 1870, and its skull, now in the Anatomical Museum of the University, was described and figured by Prof. Turner in the Transactions of the Royal Society of Edinburgh (xxvi., pp. 759-778, pl. xxix-xxx) Only a few specimens of the species are known to zoologists. 
Sowerby's Whale.

30. Mesoplodon Bidens (Śowerby).

This interesting Whale was first described by Sowerby, from a male, 16 feet in length, which was cast ashore in 1800 at Brodie, Morayshire (Brit. Miscell., pl. i.).; its imperfect slzull is now in the Oxford Museum. There is also a skull in the Edinburgh Museum of Science and Art, which Prof. Turner thinks was probably that of a second Scottish example (Tr. R. S. Edin., xxvi., p. 773). Three specimens are known to have occurred on the coasts of Ireland, and a few on those of the Continent (cf. Bell's Br. Quad., 2nd ed., pp. 431-434).

\section{Family: DELPHINIDAE.}

\section{Monodon monoceros, Linnaeus.}

Narwhal.

Only two occurrences of the Narwhal on our shores are on record. One was taken in the Firth of Forth, in June 1648, as mentioned by Tulpius (Obs. Med., p. 376), and a second entangled itself among rocks in the Sound of Weesdale, Shetland, in September 1808. This example was carefully described by Fleming (Mem. Wern. S., I., pp. 131-148). The Narwhal has only once been taken on the coast of England.

\section{Delphinapterus leucas (Pallas).}

White Whale, or Beluga.

Another rare straggler from the Arctic seas. Two young males were cast ashore from the Pentland Firth, near Thurso, in 1793, and were examined by Col. Imrie (quoted by Barclay and Neill). An adult male, 13 feet in length, was killed in the Firth of Forth in Jume 1815, and described by Barclay and Neill (Mem. Wern. S., III., pp. 371-395, pt. xvii.-xviii.); its stuffed skin is still preserved in the Edinburgh Museum of Science and Art. In Orkney, Baikie and Heddle record that a dead White Whale was stranded on Auskerry, in October 1845 (Hist. Nat. Orc., p. 22). My friend Mr. J.G. Gorclon tells me that he saw a large white Cetacean, presumably an individual of this species, in Loch Etive in June 1878; and Prof. Flower lias recently recorded the capture of a Beluga on the east coast of Sutherlandshire, near Dunrobin, in June 1879 (P. Z. S., 1879, p. 667). No English examples have hitherto been met with. 


\section{Orca gladiator (Lacépède).}

Killer, or Grampus.

Shet., Pict-Whale, Fleckit-Whale (lit., spotted-whale), Lupster, (leapster ?)

Mr. G. Gatherer informed Prof. Turner that small herds of this species are sometimes observed about Shetland, and that individuals are occasionally seen in the schools of Pilot-Whales. Eighteen were driven ashore in Bressay Sound in February 1871, and the skull of one was identified by Prof. Turner, and preserved in the Anatomical Museum of the University of Edinburgh (Tr. R. S. Edin., xxvi., pp. 469-470). Baikie and Heddle speak of the "Grampus" as being abundant about the Orkneys during the herring fishing (Hist. Nat. Orc., p. 21), and Fleming says that it frequents the Firth of Tay in pursuit of salmon (Brit. An., p. 34); but it must be remembered that fishermen and sailor's apply the names "Grampus" and "Bottle-nose" indiscriminately to all the smaller Cetaceans. A Killer, 21 feet long, was captured at Granton, in the Firtl of Forth, in March 1876, and the skeleton was obtained for the Edinburgh Museum of Science and Art.

\section{Grobicephalus melas (Trail).}

Pilot-Whale.

Shetl., Caa'ing Whale (lit. driving-whale); Orc., Bottle-nose.

Gcuel., Muc-mhara (lit., sea-sow.) (The latter names common to most smaller Cetaceans).

Herds or "schools" of this interesting species appear" about the Shetlands almost every year, and great numbers are often driven ashore by the islanders. In 1834 a shoal of 780 was thus captured at Sumburgh (Bell's Br. Quad., 1st ed., p. 485); in September 1845 no less than 1,540 are said to have been taken in Quendall Bay (Zoologist, 1846, 1. 1207); and, in 1852 about 1,100 were seen near Scalloway, but escaped (Martin's Life of Aytoun). In Orkney they are not so often seen, and are said to be rarer of late years (tom. cit.). Baikie and Heddle say that they appear there in herds of from 50 to upwards of 500 (Hist. Nat. Orc., p. 21). Among the Hebrides the occurrence of the Pilot-Whale is only occasional, but several large shoals have been recorded. In 1805 a herd of about 500 appeared, and more than 300 were taken, and in 1832 
92 were captured at Stornoway (Nat. Libr., xvi., pp. 214-215). In July 1869 about 200 visited the same place, and were almost all secured. The coasts of the mainland of Scotland are more rarely visited, but in April 1867 a school, estimated at 200, entered the Firth of Forth, between 20 and 30 of them being secured (Alston, Zoologist, 1867, pp. 801-803). These specimens were well utilized in the cause of science; one of them afforded the material for Dr. Murie's excellent monograph of the anatomy of the species (Tr. Z. S., vin., pp. 235-301); the structure of another was described by Prof. Turner (Jour. Anat. and Phys., II., pp. 66-79); the skeleton of a third is in the Edinburgh Museum of ścience and Art; and that of a fourth in the Museum of the University of Glasgow. A single Pilot-Whale was cast up on the Berwickshire coast in 1856 (Hardy, Zoologist, 1856, p. 5095), and straggler's have occurred on the shores of England, and even in the Channel (Bell's Br. Quad., 2nd ed., p. 454).

\section{Phocoena communis, $F$. Cuvier.}

Porpoise.

Shetl., Nisack (from Norse, Nisse, a hobgoblin?).

Scot., Pelloch (from the Gaelic?)

Gael., Puthag (lit., the blower).

By far the commonest Scottish Cetacean, and especially abundant among the Islands. Both Low and Baikie and Heddle observe that they appear to be migratory in Orkney, none being seen in winter' (Fcure. Orc., 1. 163; IIist. Nat. Orc., p. 21), and the same observation has been made in the north of Europe and in Greenland.

\section{Delphinus tursio, Fabricius.}

Bottle-nosed Dolphin.

The only Scottish specimens of which I lave been able to learn are two, the skeletons of which are preserved in the Museum of Science and Art and the Museum of Surgeons' Hall, Edinburgh, and which are stated to have been captured many years ago in the Firth of Forth (cf. Bell's Br. Quad., 2nd ed., p. 468). Dr. Murie informs me that herds of this species sometimes appear off the west coast.

\section{Delpimnus acutus, Gray.}

White-sided Dolplinin.

This beautiful Dolphin appear's not to be very rare in the 
Orcadian seas. It was first clescribed by Gray from an Orkney skull (Spic. Zool., No. 2), which is now in the Museum of Leyden, An adult female from the same locality was described by Knox, under the name of D. tursio (C'at. Prep. Whales, 1838), and its skeleton is now in the Edinburgh Museum of Science and Art. In August 1858 about 20 were captured in Scalpa Bay, as recorded by Dr. Duguid, who states that the species is often seen about the Orkneys (Ann. and Mag. N. H., 3rd ser., xiv., pp. 133-136). It has also been taken off the Faroes, and on the coasts of Norway and of Ireland (Ogilby, Zoologist, 1876, p. 5077).

[Delphinus Delphis, Linnceeus.-The Common Dolphin, although a more southern species than the preceding, probably occasionally visits the coasts of Scotland as it does those of Norway; but I have been unable to find a single trustworthy account of its capture. Off the south coast of England it appears not to be rare.

Demphinus albirostris, Gray.-The White-beaked Dolphin is another species whose appearance in Scottish waters is to be expected, as it seems frequently to visit the Faroes and the east coast of England (Cunninghum, P. Z.S., 1876, p. 686), but as yet its actual occurrence does not seem to have been recorded.]

\section{ORDER V.: ARTIODAC'TYLA.}

Family: CERVIDAE,

38. Cervus eiaphus, Linnaeus.

Red-Deer.

Gael., Fiach (general); Damh, Cabrach (lit., the antlered), Croichdeach (stag); Eilid, Mavlag, Maviseaclı, Adh, Grighagh (hind); Mang (young deer); Laogh (calf).

Formerly generally distributed over the mainland and Islands (excepting apparently Shetland), the Red-Deer has long been extinct in the Lowlands and in Or'kney, where antlers are found in the "Picts' houses" or "Brochs," as well as in the peit. Mr. HarvieBrown informs me that Red-Deer have also been long extinct in the Outer Hebricles south of Benbecula, although their remains are found in peat as far south as Barra. They are still preserved, however, in North Uist and the Lews, in most of the Inner Islands, and in parts of the mainland comnties of Caithness, Sutherland, Ross and Cromarty, Inverness, Banff, Aberdeen, Forfar, Perth, Stirling, 
Dumbarton, and Argyll-in all of which large tracts of land have been set aside as deer-forests. The most southern station of the Red-Deer in Scotland is the Island of Arran, where it appears to be indigenous.

[Cervus Dama, Linnaeus.-The Fallow-Deer (Gael., Dathais) thrives in parks as far north as Sutherlandshire (Harvie-Brown, P.N.H.Glasg., ri., p. 229), and exists in a semi-wild state in some places, as in Islay and Mull. Although the species existed in Britain in prehistoric times, it appears to have become extinct before the Roman period, and modern "wild" Fallow-Deer are probably all descended from escaped specimens ( $c f$. Brooke and Boyd Dawkins, Nature, xi., pp. 210, 226). Fallow-Deer were kept at Stirling by the Scottish Kings as far back as 1283, as is shown by the royal accounts (Innes" "Scotland in Middle Ages," p. $125)$.]

[Cariacus virginianus (Gmelin).-The Virginian Deer was introduced into Arran about 1832, and still thrives there, although their numbers have been reduced of late years (Alston, in Bryce's "Arvan," 4tll ed., 1872, p. 313).]

\section{Capreolus capraea, Gray.}

Roe-Deer.

Scot., Ra, Rae.

Gael., Earba, Earb; Boc-earb (Roe-buck.)

The very interesting history of the distribution of the Roe-Deer in Britain is at present being investigated by Mr. J. E. Harting. It was formerly found all over Scotland and England, as is proved, not only by remains found in peat, lake-bottoms, \&c., but by numerous allusions in history and tradition. The advance of civilization and the general destruction of forests gradually drove it back, till, at the end of the last century, it appears to have been strictly confined to the Highland counties. Pennant said that the first which were to be met with in his time (going northwards) were in the woods on the south side of Loch Rannoch. In 1792, the minister of the parish of Dingwall had only once seen a Roe (Old Stat. Acc., III., p. 5), and the species is stated to have reappeared at Little Dunkeld about 1786 (op. cit., vi., p. 362). Walker in his "Mammalia Scotica" gives only Ross, Inverness, Argyll, and Perthshire as localities (Essays Nat. IIist., 1812, p. 506). Protection and the great increase of plantations have 
worked a wonderful change, and Roe-Deer are again found in all suitable places from Sutherlandshire to Wigtownshire. They do not appear to be indigenous to any of the Scottish Islands, and are still unknown in the Outer Hebrides, Orkney and Shetland, but they were long ago introduced into Islay, and more recently into Mull and Jura.

\section{[Bovidae. $]$}

[Bos taurus, Linnaeus. - The White Bull of Cadzow and Chillingham has usually been enumerated among our existing native quadrupeds, and has been held by many zoologists to be the direct descendant of the fossil Urus or Bos primigenius (cf. infra, p. 37). The known facts of the history of the breed have lately been well collected in the Rev. J. Storer's work on the "Wild White Cattle of Great Britain" (London, 1879), but that gentleman has given far" too much credence to statements of Boethius and his copyists. To me the evidence appears overwhelmingly to prove that the modern Park Cattle are not wild survivors of the Urus, but are the descendants of a race which had cscaped from domestication, and had lived a feral life until they were enclosed in the parks and chases of the mediaeval magnates. The original Scotch herds of whose former existence we are acquainted were seven in number, namely-

I. Blair Athole (Perthshire). Broken up in 1834 (Storer, p. 345).

II. Kincardine (" Kincarnia," Perthshire), mentioned, in 1578, by Leslie (Storer, p. 137).

III. Stirling (Stirlingshire). In the Royal Park, also recorded by Leslie (Storer, p. 137).

IV. Cumbernauld (Dumbartonshire). Destroyed by the Earl of Lennox in 1570, according to Dalzell, but stated by tradition to have survived till the last century (Storer, p. 322).

V. Cadzow (Lanarkshire). The only existing herd, now numbering over forty head (Storer, p. 338).

VI. Auchencruive (Ayrshire). Destroyed late in the last century (Storer, p. 329).

VII. Drumlanrig (Dumfriesshire). Also exterminated towards the end of the last century (Storer, p. 328). 
Besides these ancient herds, attempts have at various times been made to establish White Cattle in other parks, as at Taymouth, Dalkeith, Ardrossan, and Kilmory, but, according to Mr. Storer, they now only survive at the last-named place, and are considered to be in a semi-domesticated state.]

\section{ORDER VI.: GLIRES.}

'SCIURIDAR.

\section{Sciurus vulgaris, Limnaers.}

Squirrel.

Old Scot., Comn (Sir D. Lindsay); (Sw., ikom, ekorre, a squirrel). Gruel., Fheorag (lit., the alert).

The history of the distribution of the Squirrel in Scotland is similar to that of the Roe-Deer, and is being fully worked out by Mr. Harvie-Brown, so that a mere sketch will be here sufficient. In the middle ages it appears to have been widely spread, being found in 1630 even in Sutherlandshire (Sir R. Gordon), but, owing doubtless to the same causes which banished the Roe-Deer, it became very rare, if not extinct. Subsequently it was re-introduced by several landowners in the last and present centuries, and from these centres it has gradually spread once more over the mainland, reaching Sutherlandshire about 1869 (Alston and Harvie-Brown, P. N. H. S. Glasg., II., p. 144), and South Ayrshire, where it was long absent, in 1877. It is not found in any of the Scottish Islands.

\section{[Myoxidat.]}

[Muscardinus aveluanarius (Limnaeus). - The Dormouse is included in Walker's "Mammalia Scotica" (Essays Nat. Hist., p. 499), but without any special locality, and is stated by Fleming to be "rare in Scotland" (Brit. An., p. 22). It was "reported" to Macgillivray " to occur" near Gifford, in East Lothian" (Nat. Libr., xxiı., p. 236), and is included in a list of the animals of Careston, in Forfarshire (New Stat. Acc. Forf., p. 523), but I have been quite unsuccessful in seeking for any confirmation of these vague statements.] 


\section{MURIDaE.}

\section{Mus rattus, Linnaeus.}

Black Rat.

Scot., Ratton, Rotten (common to next species). Orc., Blue Rat. Gael., Radan (common to next species).

Appears to be almost extinct as a native species, although examples sometimes occur near sea-ports; thus Mr. J. M. Campbell lately showed me a fine specimen which was killed on a wharf at Glasgow in 1874. The Rev. G. Gordon, who recorded the existence of the Black Rat in Morayshire in 1844. (Zoologist, 1844, p. 424), informs me that it is now quite extinct there; but it is stated by Mr. H. Stewart to be still found in Wigtownshire (Field, $23 r d$ Aug., 1879). In 1848 the Black Rat was confined in Orkney to South Ronaldshay, as recorded both by Baikie and Heddle (Hist. Nat. Orc., p. 15), and by Wolley (Zoologist, 1849, p. 2344); and it appears to have been owing to this that a belief became prevalent that the Hamster (Cricetus frumentarius, Pallas) had become naturalised in that island (Hist. Nat. Orc., p. 16). In investigating the range of the Black Rat it must be remembered that the black variety of the Water Vole is very often confused with Mus rattus.

\section{Mus decunanus, Pallas.}

Brown Rat.

Scot. and Gael. (see last species).

Seems to have invaded the south of Scotland from England about the middle of the last century, first appearing in Selkirkshire between 1770 and 1777 (New Stat. Acc. Peeblessh., p. 136). In Morayshire the Rev. G. Gordon says that Brown Rats arrived at the sea-ports about 1814 (Zoologist, 1844, p. 424). In Orkney, Baikie and Heddle state that they have become very numerous, but in Rousay they suddenly died out about 1836, and there were none in 1848 in Enhallow or in Damsay (Hist. Nat. Orc., p. 15). They were introduced into Mull from a wrecked vessel, and were at first treated as pets by the inhabitants. The species is now universally distributed both on the mainland and in the Islands, being found even on uninhabited islets in the Sound of Harris, where they feed principally on molluses. 
43. Mus nusculus, Linnaens.

House-Mouse.

Gael., Luch.

Universally distributed wherever there are human habitations. Baikie and Heddle state, however, that, like the last species, Mice are absent from the islands of Enhallow and Damsay (Hist. Nat. Orc., p. 15). They are abundant in the Outer Hebrides.

\section{Mus sylvaticus, Linnaeus.}

Wood-Mouse, Long-tailed Field-Mouse.

A common species throughout the whole of the mainland, in Orkney (Hist. Nat. Orc., p. 14), and in most, if not all, of the Inner Islands; but I have not been able to obtain any positive evidence of its existence in the Outer Hebrides or in Shetland.

\section{Mus minutus, Pallas.}

Harvest Mouse.

Appear's to be generally but locally distributed in the eastern Lowland counties, but to be absent in the west, although it is not rare in the north-west of England. W. Macgillivray has recorded it from Midlothian, Fifeshire, and Aberdeenshire (Nat. Libr., xxı., p. 257), it is included in a list of the animals of Alloa, and its size and weight correctly noted (New Stat. Acc. Clackmannansh., p. 9), and Mr. R. Gray informs me that he caught one in Kincardineshire in 1869. This eastern distribution in Scotland of a comparatively southern form is interesting as analogous to the range of certain birds, as commented on by Messirs. Gray and Anderson in their "Birds of Ayr" and Wigtown" (p. 4).

[What is the "Button-Mouse," reported to Baikie and Heddle to exist in Orkney, only two inches long, and "frequently found asleep, rolled up in the shape of a ball" (Hist. Nat. Orc., p. 15, foot-note)?]

\section{Arvicola agrestis, De Selys.}

Common Field-Vole, Short-tailed Field-Mouse.

Scot., Water-Mouse.

Gael., Iuch-fheior (lit., grass-mouse.)

Common throughout the mainland, in the Inner Islands, and in Orkney (Hist. Nat. Orc., p. 16), but not found in Shetland. In the Outer Hebrides it was not met with by W. Macgillivray, but was 
reported to Mr. Harvie-Brown by the late Capt. M'Donald of Rodil, and by Mr. Henderson, Loch Boisdale; and in $1879 \mathrm{Mr}$. Harvie-Brown captured a specimen, now in the British Museum, at Newton, North Uist. Occasionally appears in vastly increased numbers, and is then extremely destructive. This took place to a great extent in the south-eastern counties in the spring and summer of 1876 .

\section{Arvicola glareolus (Schreber).}

Red Field-Vole, Bank-Vole.

First noticed in Scotland by W. Macgillivray (Nat. Libr., xxiı, p. 257), and appears to be widely but locally distributed. It has not yet been recorded, however, from further north than Morayshire, where the Rev. G. Gordon informs me that it is extremely common, nor from any of the Islands.

\section{Arvicola ampinibius (Linnaerus).}

Water-Vole or Water-Rat.

Gael., Radan-uisge (lit., water-rat).

Very generally distributed on the mainland, and is found, though apparently not plentifully, in Orkney (Hist. Nat. Orc., Addenda). I have no satisfactory evidence of its existence in the Inner Islands, though it is said to be found in Islay and Mull, and it is certainly absent from the Outer Hebrides. The black variety, which W. Macgillivray described as distinct under the name of Arvicola ater (Mem. Wern. S., VI., p. 424), is local rather than rare, and has been met with in Sutherland (Alston and HarvieBrown, P. N. H. S. Glasg., II., p. 145), Banff, Aberdeen (Macgillivray, loc. cit.), Midlothian, Stirling, Dumbarton, and Lanarkshire.

\section{Family: LEPORIDAE.}

49. Lepus iuropaeus, Pallas.

Common Hare.

Scot., Maukin, Bawd (Aberdeensh., also Old English. These names appear to be forms of malkin and bawdrons, old English and Scottish names for the Cat, and to have been transferred to the Hare, just as the name pruss often is in popular language).

Gael., Gearr (lit., short-tailed), Maidheach (from Gael., magh, a plain), Miol baidhe (lit., yellow-beast.) 
Generally distributed in the Lowlands, local in the Highlands; in west Sutherlandshire rare, and confined to the limestone district of Assynt (Alston and Harvie-Brown, P. A. H. S. Glasg., II., p. 146). 'The species does not appear to be indigenous in any of the Islands, but has been very generally introduced. It was first brought to the Lews by Seaforth, shortly before 1797 (Old Stat. Acc., xix., p. 272), and became numerous, but is said now to be decreasing; was introduced into Coll about 1787 (op. cit., x., p. 401), into Mull in 1814 or 1815, and into Orkney in 1832, where, in 1848, Hares were abundant in the Mainland and in Hoy (Hist. Nat. Orc., p. 16).

\section{Lepus variabilis, Pallas.}

Mountain Hare.

Scot., Blue Hare, White Hare.

Gael., Maidheach-geal (lit., white hare).

Very numerous throughout the Highlands, but does not appear to be indigenous in the Outer Hebrides, where Mr. Harvie-Brown was informed that it was first turned out about 1850 ; it is also stated to have been only recently introduced into Mull. In Orkney they are said to have been formerly found, as is shown by a passage in Sibbald's "Scotia Illustrata," and by a 17th century manuscript, quoted by Baikie and Heddle (Hist. Nat. Orc., p. 17), but they have long been extinct. About twenty years ago the Mountain Hare was introduced into the south-western hill-country, and it is now not rare in many of the upland districts of Peeblesshire, Ayrshire, and Lanarkshire (Alston, Faunc W. Scotl., p. viii).

\section{Lepus cuniculus, Limnaers.}

Rabbit.

Gael. Coinein, Coineanach (from old English coney?).

Old Scot. and Orc., Cuning.

A rapidly-spreading species in Scotland, and may now be said to be universally distributed, although local in the Highlands owing to the character of the country; but forty or fifty years ago Rabbits were unknown in many parts even of the Lowlands where they now abound. They appear to have been introduced into the Islands, and must have been long established in Orkney, for Martin states that their skins were an article of export in 1715 West. Isles, p. 357), and in 1795 no fewer than 36,000 skins were 
sold at Stromness (Old Stut. Acc., Xvi., p. 448). At the end of the last century they abounded in Colonsay (op. cit., xiI., p. 329), and early in the present they were introduced into Mull, where they are now very plentiful. Professor Duns says that they have not thriven in the Lews, but the contrary is the case in almost all the other Western Islands.

\title{
II. FOSSIL AND EXTINCT SPECIES.
}

\author{
ORDER I. CARNIVORA. \\ Family: CANIDAE.
}

Wolf.

Gael., Frol, Mhadadh-alluidh (lit., savage hound), Lub, Allamadadh, Mactire (lit. earth's son).

Of extinct Scottish Mammals the Wolf comes first in systematic order, but last in date of extirpsution. My friend, Mr. J. E. Harting, has recently discussed the history of "The Extinct British Wolf" (Pop. Science Review, 1878, pp. 53-61, 141-154, 251266, 396-406), and I must here confine myself to the most important records of its existence in Scotland. The oldest evidence is afforded by the semi-fossil skulls which have been found in marl in Forfarshire (Lyell, Princ. of Geol., 11., p. 536) and elsewhere, and the roll is carried on by popular tradition and by allusions in the older chronicles and charters. In 1427 James I. passed an act which contained a chapter "of Wolf-birdis," whereby the Barons of the realm were ordered to "chaise and seik the quhelpis of the wolfis and gar slay thame." "Ilk man not rysand with the Barrone" was fined a wedder, but the nobles appear to have wished to keep the sport to themselves, for it was further ordained "that na man seik the wolf witl schot, bot allanerlie in the tymes of hunting of thame." Twenty years later, an Act of James II. removed this latter restriction, placing the affair in the hands of "the Scherif or the Baillies" of each county, and directing that "he that slayeis ane wolf in ony time" is to receive a penny from each householder in the parish. Wolves were included in the game lists of the great hunting parties at which the successive 
Earls of Athole entertained James V. in 1528, and Queen Mary in 1563 , and there is abundant proof of their existence in the next century. Sir Ewan Cameron of Lochiel is traditionally said to have slain the last in Lochaber in 1680, and this has till recently been always quoted as the last Scottish Wolf; but there is good traditional evidence that the brutes lingered much later in other parts of the Highlands. The last in Morayshire, and probably in Scotland, is said to have been slain by M'Queen of Pall-a-chrocain in 1743, and as that celebrated sportsman lived till 1797 the tradition was still fresh when two versions of it were independently recorded by the brother's Stuart, in the notes to their "Lays of the Deer Forest," and by Sir Thomas Dick Lander, in his wellknown "Account of the Moray Floods of 1829." For further" details on this interesting subject I must refer the reader to Mr. Harting's excellent papers quoted above, and to Mr. J. Hardy's observations, published in the "History of the Berwickshire Naturalists' Club" (Iv., pp. 268-292, vi., pp. 129-130).

\section{Family: URSIDAE.}

2. URsus arctos, Linnceus.

Brown Bear:

Old Scot., Bar.

Gael., Math-ghamhaimn, Mathan.

A skull and rib of the Brown Bear, found in a semi-fossil condition in peat moss in Dumfriesshire, was identified by the late Sir Wm. Jardine, and recorded by Dr. J. A. Smith (P. S. Antiq. Scotland, virr., p. 216). This skull, Dr. Smith informs me, was purchased by him at the sale of the Applegarth collection, and presented to the Museum of the Royal Society of Antiquaries of Scotland. The species probably was exterminated at a comparatively early period, for although British Bears are mentioned by several classical writers (as Martial, Claudian, \&c.), and once or twice in Saxon chronicles, there is no satisfactory record of their existence later than the ninth or tentl century. In Gaelic tradition the Bear appears in some mythical tales (Campbell, Tales of W. Highlands, r., pp. 164-175), and is said to have given their name to the Mc Mhathains or Mathisons (Notes and Queries, 6th ser., xI., p. 105), but there appear to be now only vague traditions of its existence as a Scottish beast of chase. 


\title{
ORDER II.: PROBOSCIDEA.
}

\author{
Family: ELEPHANIIDAE.
}

\section{Elephas primigenius, Blumenbach.}

Fossil Elephant or Mammoth.

Remains of the Mammoth have been found in Scotland, both under and in the boulder-clay, the Rein-Deer being the only other Scottish Mammal whose bones have yet been found in deposits of such antiquity. A tusk was found between Edinburgh and Falkirk, and bones near Kilmaurs (Bald., Mem. Wern. Soc., Iv., pp. 58-64), near Airdrie (Craig, P. Geol. S. Glasg., III., p. 415), and at Cliftonhall (Cat. Western Scott. Fossils, p. 152), and a molar tooth, now in the Hunterian Museum of the University of Glasgow, near Bishopbriggs (Bryce, Geol. Arran and Clydesd.). Besides these, Professor W. Boyd Dawkins informs me that there are remains from Caithness-shire in the Kelvingrove Museum at Glasgow, and Mr. J. Kirsop tells me that he has a well preserved molar found at Baillieston, near Glasgow.

\section{ORDER III.: PERISSODACTYLA.}

\section{Family: EQUIDAE}

\section{Equus caballus, Linnaeus.}

\section{Fossil Horse.}

Bones of a small Horse, not distinguishable from the recent species, have been found in marl in Forfarshire (Lyell, Princ. Geol. II., p. 336), and in peat in Renfrewshire (Craig, Tr. Geol. S. Glasg., IV., p. 18). The latter specimens are preserved in the Hunterian Museum of the University of Glasgow. There is no reason to believe that the Horse survived in Scotland in a really wild state in historical times, although Boethius mentions Equi feri in the sixteentl century (Reg. Se. Descr., fol. ix.), and John Taylor, in his "Pennyles Pilgrimage," speaks of having seen "wild horses" in Braemar in 1618, for in botll cases ordinarv hill-ponies are probably meant. 


\section{[Family: RIINOCERONTIDAE']}

[RHinoceros, sp.?-Horns of a Rhinoceros are stated to have been found in marl-pits in Forfarshire, and in Blair-Drummond Moss (Fleming, New Pliil. Journ., xI., p. 297), but it seems probably that the specimens in question were the horn-sheaths of one of the Fossil Oxen (cf. Smith, 'P. S. Antiq. Scotland, Ix., pp. 636-638).]

\section{ORDER IV.: ARTIODACTYLA. \\ Family: SUIDAE.}

5. Sus sCrofa, Linnaens.

Wild Boar.

Old Scot., Baar (Ang.-Sax., bar, a boar).

Gael., Torc, Torc-neimh (lit., fierce boar), Cullach, Fiadh-chullach (lit., wild swine).

Scottish Wild Boars have not only left their remains in marl-pits and peat-bogs (Lyell, Princ. Geol., II., p. 356), but have had their memory preserved both in tradition and in history. In Gaelic they are mentioned as beasts of chase in the Fionnean fragments of poetry, and they play an important part in such mythical legends as that of "Diarmid and the Magic Boar" (cf. Campbell, Tales of the West Highlands, I., p. xci., III., pp. 36-90, Iv., p. 168). When the Baron of Avenel granted certain rights in Eskdale to the monks of Melrose in the reign of Malcolm IV. (1153-1165) he specially reserved the right of hunting the Wild Boar (Morton, Ann. T'eviotclale, p. 273), but in the next century Boars appear to have required special protection, for in 1263 there is an item in the accounts of the Sheriff of Forfar for corn for the Porci sylvestris (Innes, Scotl. in Middle Ages, p. 123). How much later they existed in Scotland, I have been unable to ascertain.

\section{Family: CERVIDAE.}

\section{Alces machlis, Ogilby.}

Elk.

Gael., Lon (iit., food, a beast fit for food), Miol (lit., the wild beast).

The palaeontological evidence that the true Elk was formerly a native of Scotland has been fully discussed in Dr. J. A. Smith's 
excellent memoir (P. S. Antiq. Scotland, Ix., pp. 297-345), where will be found full details of the discovery of its remains in Sutherland, Perth, Forfar, East and Mid Lothian, Roxburgh, Selkirk, Peebles, and Berwickshire. In England its antlers have been found associated with Romano-British remains, but historic evidence of its date of extinction in Britain is wanting. Aldrovandus quotes Julius Capitolinus as to certain Cervi palmati which were brought from Britain, and exhibited in the games of the Emperor Gordian (in the 4th century), but there can be no certainty as to the species meant (cf. Scoular, J. Geol. Soc. Dublin, I., pp. $197-$ 209). Whittaker, in his "History of Manchester," suggests, that the traditional animal named Segh by the Welsh may have been the Elk, and the Highlanders still preserve stories of a gigantic extinct Deer, which they term either Miol (Scrope, Days of Deerstalking, p. 344, foot-note) or Lon. In the older fragments of Gaelic poetry it is described as the chief object of the chase of Fionn and his followers, and several descriptive epithets are applied to it, as luath, swift, dubh, black or dark, and spagach, shambling (Campbell, Tales of W. Highlconds, Ir., p. 102, IV., pp. 163, 255). An ancient poem, quoted by the brother's Stuart in their "Lays of the Deer Forest" (II., p. 9), alludes to the Lon as a woodland animal-

which they translate-

"'Us gòrm mheall-àild nam mile guibhas,

Nan lùb, nan earba, 's nan lon."

"The blue height of a thousand pines,

Of Wolves and Roes and of Elks."

It does not appear improbable that the Elk may have survived in the great norther'n forests to a comparatively late period, and corroborative evidence is afforded by the fresh condition of a shed antler, discovered in Strath Halladale, Sutherlandshire, which is stated by Dr. Smith to have "apparently lost nothing of its animal or mineral constituents."

\section{Rangifer tarandus (Linncleus).}

Rein-Deer.

As in the case of the Elk, we are indebted to Dr. J. A. Smith for a careful study of the history of the Rein-Deer as a Scottish species (P. Soc. Antiq. Scotland, vili., pp. 186-222), and I must refer the reader to his excellent paper for full details of the discovery of its remains in Orkney, Caithness, Sutherland, Ross, West Lothian, 
Lanark, Dumbarton, Ayr, and Dumfriesshire. These have been found both under the boulder-clay and in comparatively recent deposits, and in Caithness and Sutherland they are associated with human remains in the ruined "Brochs." Attention was long ago directed by Fleming (Brit. An., p. 27) to a passage in Torfaeus in which lie states that the Jarls of Orkney of the 12th century were in the labit of passing over to Caithness to chase the Roe and Rein-Deer (Rer. Orcad. Hist., lib. i., cap. xxxvi.). The source from which Torfaeus copied was undoubtedly the "Orkneyinga Saga," and the original passage in Jonas Jonaeus' editio princeps (Hafniae, 1780, p. 384) is as follows:-

"Thar var sithr Jarla naer hvert sumar at far: yfer á Katanes oc thar upp á merkr at veida rauddyri edr hreína."

This Jonaeus renders-

"Solebant Comites quavis fere aestate in Katenesum transire ibique in desertis feras rubras \& rangiferos venari."

In the English edition of Jon A. Hjaltalin and G. Goudie (Edinburgh, 1873, p. 182) the words are translated-

"Every summer the Earls were wont to go over to Caithness and up into the forests to hunt the red-deer or the rein-deer."

Through the kindness of Professor Newton I have obtained the opinion of the celebrated Icelandic scholar Mr. Eiríkr Magnusson, of Cambridge, who informs me that neither version is quite correct as regards the latter words. The literal translation is-

"It was the custom for the Earls (Rögnvald and Harald) nearly every summer to go over into Caithness and then up into the woods to hunt reddeer or reins."

Mr. Magnusson further observes that the word $e d r$ has two meanings, equivalent to the Latin sive and vel, and le therefore considers it uncertain whether the proper reading is that they went to hunt either Red-Deer or Rein-Deer, or whether, as appears to lim more likely, the Sagaman was under the impression that rauddy. and hrein were symonymous terms.

It will thus be seen that the evidence of the "Orkneyinga Saga" as to the survival of Rein-Deer in Scotland till the 12th century is much less positive than lias been generally represented. On the other hand, it receives a certain amount of confirmation from the fact already noticed, that remains of the animals have been found in the ruined "Brochs" of the northern counties, and also from a rude figure on a sculptured stone, copied by Dr. Smith, which certainly appears to be intended to represent a Rein-Deer. This 
stone, which was found near Grantown, Inverness-shire, is now in the Museum of the Society of Antiquaries at Edinburgh, and both the general pose and the development of the antlers seem to preclude the possibility of its being intended to represent a Stag.

\section{Megaceros giganteus (Blumenbach).}

Gigantic Irish Deer.

Remains of the true Elk appear to have been frequently mistaken for those of this species, and Dr. J. A. Srnith has only been able to find two authenticated instances of the occurrence of remains of the Gigantic Deer in Scotland-namely, a skull, found at Maybole, Ayrshire, in marl, and two portions of antlers at Crofthead, Renfrewshire, in laminated clay, which probably date from the glacial epoch. In both cases the remains were associated with those of Bos primigenius, and in the latter (which are preserved in the Hunterian Museum of the University of Glasgow) with Equus caballus (P. S. Antiq. Scotland, Ix., pp. 345-350). The evidence which has been brought forward as to the survival of the Gigantic Deer in historical times appears to be quite untrustworthy ( $c f$. Scoular, J. Geol. Soc. Dublin, I., 197-209).

\section{Family: BOVIDAE.}

\section{Bos primigenius, Bojanus.}

Gigantic Fossil Ox, or Urus.

As in the case of the Deer, the history of the discovery in Scotland of remains of Fossil Oxen has been carefully reviewed by Dr. J. A. Smith (P. S. Antiq. Scotland, Ix. pp. 587-674), who has collected records of the occurrence of bones of the present species in Orkney, Caithness, Sutherland, Aberdeen, Perth, Fife, Lanark, Renfrew, Ayr, Kirkcudbright, Dumfries, Berwick, Roxburgh, and Selkirkshire. Almost all these remains have been found in deposits of comparatively recent date, those in Orkney and Caithnessshire being discovered in the ruins of early human habitations, while skulls found in marl-beds in Selkirkshire were associated with bronze weapons. There is no authentic evidence, however, that the Urus survived in these islands to historical times, for the records of Boethius and other mediaeval chroniclers of gigantic Wild Oxen existing in Scotland up to the 16th century appear to be quite untrustworthy, and the claim that has been set up for the 
park breed of White Cattle as being their direct descendants is quite unsupported by what little we know of their history (cf. supra, p. 25$)$.

\section{Bos Longifrons, Owen.}

Smaller Fossil Ox.

In the paper referred to under the last species, Dr. J. A. Smith has shown that remains of the Smaller Fossil Ox have been found in the Hebrides and Orkney, as well as in Caithness, Sutherland, Ross, Forfar, Kincardine, Stirling, Lanark, East, West, and Mid Lothian, Wigtown, Kirkcudbright, and Roxburghshire. They are often associated with remains of human industry, and may in some cases have belonged to domesticated animals. In geological age there appears to be now no doubt that this species is even more recent than the last, and all the evidence seems to point to its being the ancestor of the short-horned races of our domestic Cattle.

ORDER V.: GLIRES.

Family: CASTORIDAE.

11. Castor fiber, Linncleus.

Beaver.

Gael., Losleathan, Dobliran-losleathan (lit., broad-tail, broadtailed otter'; cf. Welsh Llosdlydan; Irish, Davaran-loisleathan); Beathodach (from Old Gael. beath's, water).

The palacontological and traditionary evidence of the existence of the Beaver in Scotland has been investigated by Neill (Edin. Phil. Journ., I., Pp. 177-187), and by Dr. C. Wilson (New Phil. Journ., 2nd Ser., vili., pp. 1-40). The first recorded sub-fossil skull was one from Perthshire, presented by Dr. Farquharson to the Scottish Society of Antiquaries in 1785; others have been since found in Roxburghshire and Berwickshire. Of its range into the historical period the evidence is not very satisfactory. In the 12 th century, Giraldus de Barri, who met with Beavers in Wales, was informed that they still existed in one river in Scotland, but were rare (Itiner. Cambr., lib. ii., cap. 3). In a capitular of export duties of David I. (1124-1153), skins of Beveris are included (Acts Parl. Scotl., I., p. 303); but they are not mentioned in a similar act of 
1424. The late Prof. Cosmo Innes, however, pointed out to me that too much trust must not be given to these documents, as the lists of commodities appear in some cases to have been adopted from similar English or foreign enactments. Boethius includes Fibri among the wild animals which were found round Loch Ness "incomparabile numero" (Regn. Sc. Desc., 1527, fol. ix.), and Bellenden follows him, but, as usual, little or no reliance can be placed in his testimony, which was probably founded on hearsay. Traditions of the "Broad-tailed Otter" survive in many parts of the Highlands, and the animal is said once to have been plentiful in Lochaber (Neill, l.c.); but it was probably extinct long before the time of Boethius.

\section{O N C L USION.}

In bringing this article to an end, I would wish to point out to Scottish field-naturalists that the distribution of Mammalian life requires revision, especially in the Islands. The Shrews, Mice, and Voles especially deserve attention, as does the supposed occurrence of the Greenland and Ringed Seals in Scottish waters. More accurate records of the visits of the rarer Cetaceans are much to be desired, and the gradual extencion of range of some of the terrestrial Mammals, as the Hedgehog, Mole, Squirrel, and Roe-Deer, deserve careful investigation. Till further information has been collected on these points our knowledge of our native Mammals cannot be considered satisfactory.

Finally, I desire to express my special thanks to my friend, $\mathrm{Mr}$. J. B. Murdoch, of Langside, for his kind assistance in seeing the foregoing pages through the press. 



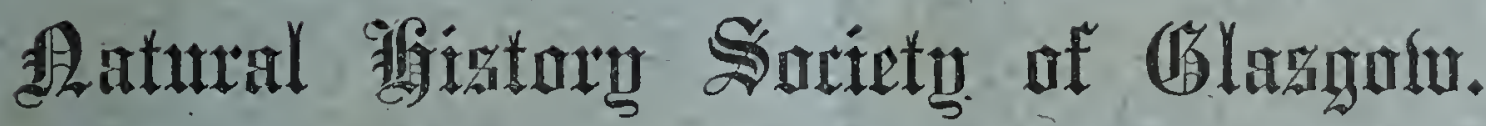

FOUNDED $185 i$.

\section{SESSION 1879-80.}

\author{
gresionent.
}

Pror. JOHN YOUNG, M.D., F.G.S.

\section{औice-gestesionts.}

JOHN YOUNG, F.G.S., J. A. HARVIE-BROIVN; IV. J. MILLIGAN.

\section{Secretarp.}

RoBERT MASON, 6 Álbion Crescen't, Dowanmul.

\section{erexturer.}

R. J. BENNETT, 50 Gordon S'TREet.

apibrantan.

HenRy C. YOUNG, Forth Street, Pont-Dundas.

Trie Society has for its aim the encouragement of the pursuit of Natural

History in all its branches. It holds meetings at which specimens may be exhibited, and papers and other communications read. These take place from September to April, on the last Tuesday in each month, in the Society's Rooms, Anderson's College, 204 George Street.

Excursions are also arranged to localities of interest in the district, from May to September.

Members' Amual Subscription, 5s.; Entry-money, 10s.

\section{PUBLICATIONS}

OF TIE

\section{NATURAL HISTORY SOCIETY OF GLASGOW.}

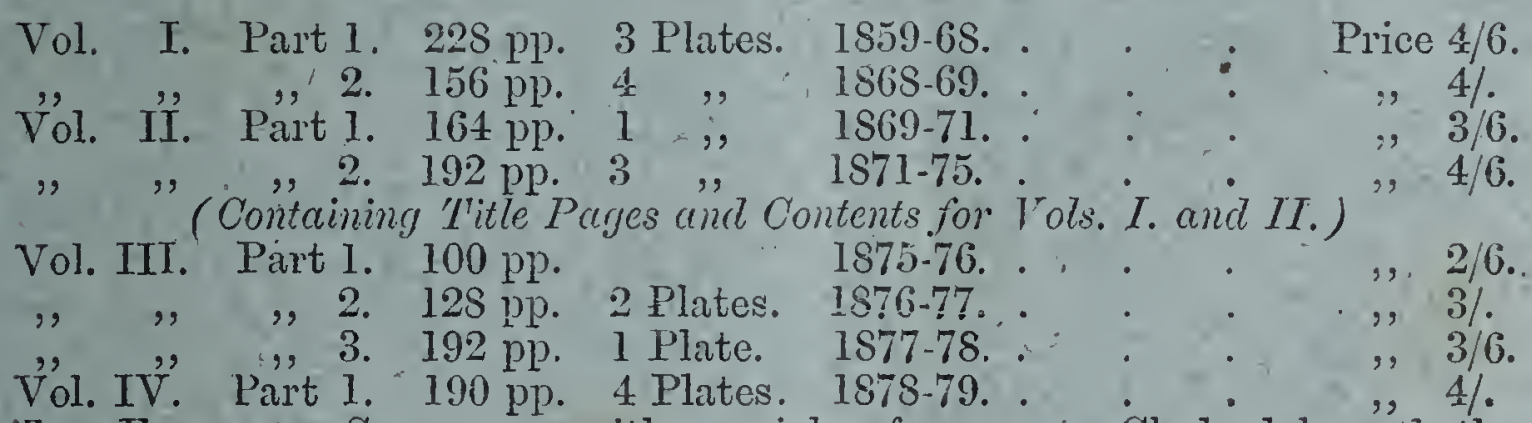

The Fauna of Scotuand, with special reference to Clydesdale and the

\section{Western District.}

Hymenoptern-Part I. By Mr. P. Cameron, 187S. Price 1/6. Mammalia. By Edward R. Alston, F.L.S., F.G.S.

Crustacea-Part I., Ostracoda. By David Robertsol1, F. L.S., F.G.S. Various other Lists are nearly ready for publication.

A Catalogue of the British Tenthredinidae (printed on one side of the leaf for collectors). By Mr. Peter Cameron, IS7S. - Price 1/.

Notes ON THE FAUNA AND FLURA OF THE WEST OF SCOTLAND, with Lists. Small Sro. Compiled for the Meeting of the British Association, held in Glasgow, September, 1876. Price 2/. 


\section{THE FAUNA OF SCOTLAND;}

\section{WITH SPECIAL REFERENCE TO CLYDESDALE AND THE}

WESTERN DISTRICT.

TuE Natural History Society of Glasgow, having resolvecl to publish Catalogues of the Fauna of Scotland, with special reference to Clydesdale and the Western District, requests the co-operation of all interested in Scottish Zoology. The following zoologists have agreed to draw up lists of the species in the rarious groups to which their names are appended. Any observers who can furuish information regarding the distribution of species, the variations which they undergo in particular localities, the altitudes which thcy' reach, and generally any notes bearing on the subject, will further the object in view by eommunieating with these gentlemen, the lists being now in preparation.

The Council will also be glad to hear from any zoologists (whether memiers of the Society or not) who would undertake to prepare Catalogues of those elasses for which no compilers have as yet been obtained.

As far as possible, the Catalogues will be drawn up on one uniform plan, and of the same size as the Proceedings of the Society, with which they will be issued to the memhers, although paged apart for future collection. A limited number of copies will also be printed for separate sale.

\section{Rhizopoda,}

Actinozod,

Echinoidea,

Stellerida,

Mollusca,

Acarina,

Araneina,

Arthrogastra,

Myriopoda,

Thyscunoptera,

Mallopteaga, .

Thansoptera,

Orthoptera,

Tr:ichoptera,

Diptera (in part), .

Hymenopterc (Part I. issued),

Pisces,

Reptilia,

Amplibiac

Mammalia (Issued),

Aves,
}

Crustacec (Part I., Ostracoda, Issued). .
David Robertson, F.L.S., F.G.S. (42 Kelvingrove Street, Glasgow.)

Do.

Do.

Do.

Do.

Do.

Peter Camcron.

(23 Royal Excliange Square, Glasgow.)

Henry C. Young.

(Forth street, Port-Dundas.)

Do.

Peter Cameron.

Do.

Do.

Do.

Do.

Francis G. Binnie.

Do.

Peter Cameron.

David Robertson, F.L.S., F.G.S.

I. R. Alston, F.L.S., F.G.S.

(14 Madilox Street, London, W.)

Do:

Do.
James Lumsclen, F.Z.S.

(Arden, bumbartonshire.) 